УДК 611.018.34-62.1

DOI

(C)А. Б. Воробець ${ }^{1}$, П. А. Гасюк ${ }^{1}$, О. П. Костиренко ${ }^{2}$

ДВНЗ «Тернопільський державний медичний університет

імені І. Я. Горбачевського» ${ }^{1}$

ВДНЗ України «Українська медична стоматологічна академія», м. Полтава²

\title{
Особливості структурної організації навколопульпарного дентину великих кутніх зубів залежно від статі
}

Резюме. У статті наведено дані гістохімічних, мікроскопічних та морфометричних досліджень шліфів великих кутніх зубів. Дослідження проводили окремо на чоловічих та жіночих зубах із метою встановлення різниці у структурній організації дентину великих кутніх зубів залежно від статі. 3 проведених мікроскопічних досліджень декальцинованих великих кутніх зубів виявлено, що структура одонтобластів та їх монопедичних відростків дещо відрізняється у чоловіків порівняно з жінками. 3 результатів морфометричних досліджень щільності дентинних канальців на площу поля зору встановлено, що у чоловіків цей показник більший, ніж у жінок за рахунок потовщення перитубулярного дентину.

Ключові слова: навколопульпарний дентин, дентинні канальця, дентинні відростки, предентин, одонтобласти, перитубулярний дентин.

\section{А. Б. Воробец ${ }^{1}$ П. А. Гасюк ${ }^{1}$, А. П. Костыренко ${ }^{2}$}

ГВУЗ «Тернопольский государственный медицинский университет

имени И. Я. Горбачевского» ${ }^{1}$

ВГУЗ Украины «Украинская медицинския стоматологическая академия»,

г. Полтава ${ }^{2}$

\section{Особенности структурной организации околопульпарного дентина больших коренных зубов в зависимости от пола}

Резюме. В статье приведены данные гистохимических, микроскопических и морфометрических исследований шлифов больших коренных зубов. Исследования проводились отдельно на мужских и женских зубах с целью установления разницы в структурной организации дентина больших коренных зубов в зависимости от пола. Проведенными микроскопическими исследованиями декальцинированных больших коренных зубов выявлено, что структура одонтобластов и их монопедических отростков несколько отличается у мужчин по сравнению с женщинами. Проведенным морфометрическим исследованием плотности дентинных канальцев на площадь поля зрения установлено, что у мужчин этот показатель больше, чем у женщин за счет утолщения перитубулярного дентина.

Ключевые слова: околопульпарный дентин, дентинные канальцы, дентинные отростки, предентин, одонтобласты, перитубулярный дентин. 


\author{
A. B. Vorobets ${ }^{1}$, P. A. Hasiuk ${ }^{1}$, O. P. Kostyrenko ${ }^{2}$ \\ I. Horbachevsky Ternopil State Medical University ${ }^{1}$ \\ HSEI of Ukraine «Ukrainian Medical Stomatological Academy» Poltava ${ }^{2}$
}

\title{
Features of the structural organization pulp around dentin of the molars, depending on sex
}

\begin{abstract}
Summary. The article presents histochemical, microscopic and morphometric data of research section of molars. Research were conducted separately to male and female teeth in order to establish differences in the structural organization of the dentin of the molars, depending on sex. Microscopic examination decalcined molars revealed that the structure of odontoblasts and monopedic processes somewhat different in men than women. Morphometric study conducted by the density of the dentinal tubules in the area of the vision found that in men, the figure more than women due to thickening of the peritubular dentin.
\end{abstract}

Key words: pulp around dentin, dentinal tubules, dentinal processes, predentin, odontoblasts.

Вступ. Відомо, що дентин - це мінералізована, безклітинна, позбавлена судин тканина зуба, яка займає проміжне положення між кістковою тканиною, цементом та емаллю. Його можна розглядати як міцелярну комбінацію з органічної матриці й неорганічних апатитових кристалів [1,2]. Дентин, порівняно 3 емаллю, $є$ менш твердою субстанцією. За даними літератури, це пов'язано з його меншою біомінералізацією та наявністю багаточисельних дентинних канальців, що пронизують основну речовину дентину. В останніх розміщуються відростки одонтобластів, тіла яких локалізуються в пульповій камері [3, 6, 9]. Саме завдяки наявності цих відростків, утворюється органічний матрикс дентину, який представлений колагеном I, II і VII типів та преколагеновими структурами $[4,10,11]$. Відомо, що колаген I типу у вигляді волокон Корфа розміщується у плащовому дентині біля емалево-дентинної межі. Колаген II типу складає основу регулярного дентину у вигляді волокон Ебнера, що розташовуються тангенціально відносно відростків одонтобластів. Якірні волокна, що з'єднують емаль 3 дентином, представлені колагеном VII типу. Навколо пульпової камери наявний предентин, представлений попередниками колагенових волокон - нейтральними глікозаміногліканами $[4,5,7]$.
Одонтобласти синтезують органічні речовини, які представлені тропоколагеном. Тропоколаген екстрацелюлярно з елементарних частин перетворюється у визначений тип колагену I, II чи VII типу. Потім відбувається відкладення на органічний матрикс мінерального компоненту, який забезпечує дентину твердість і відмежовує пульпову камеру від мікробного фактора i механічного впливу [1, 6, 7].

Розрізняють перитубулярний дентин, що являє собою високомінералізовану основну речовину дентину, яка формує стінку дентинної трубочки і ШЙКпозитивну забарвлену речовину, котра у вигляді тонких (15 мкм) поперечних смуг розміщується навколо відростків одонтобластів [11, 14].

Інтертубулярний дентин - це матрикс із середнім ступенем мінералізації, має вигляд більш товстих поперечних смуг (60-120 нм), які розміщуються навколо окремих груп дентинних відростків. При електронно-мікроскопічному дослідженні перитубулярний дентин має світлий колір, а інтертубулярний, маючи сірий колір, формує широкі поперечні смуги [13].

Матрикс із низькою мінералізацією у вигляді вузької смужки розміщується між дентином і предентином. Особливістю предентину $\epsilon$ відсутність інтертубулярного дентину, а окремі відростки одонтобластів розміщуються у вакуолізованих 
зонах дентинних трубочок [12, 15]. Необхідно відмітити, що зона предентину є початковою зоною мінералізації.

Метою дослідження було виявлення структурних особливостей будови дентину великих кутніх зубів, визначення показників щільності дентинних відростків i діаметра їx канальців у ділянці навколопульпарного дентину окремо у чоловічих та жіночих великих кутніх зубах.

Матеріали і методи. Для досягнення поставленої мети використовували великі кутні зуби чоловіків та жінок, 3 них виготовляли товсті й тонкі шліфи 3 подальшим їх забарвленням еріохромом-Т чорним, ШЙК-альціановим синім, тіоніном, пікрофуксином за ван-Гізон із наступним вивченням у прохідному та поляризаційному світлі. Досліджуваний матеріал було поділено на дві групи: великі кутні зуби чоловіків та жінок. При цьому проводили розпили коронки цих зубів як у вертикальному, так і в горизонтальному напрямках. Одержані товсті шліфи полірували до отримання дзеркальної поверхні, а потім проводили комплекс різних гістохімічних реакцій для виявлення компонентів матриксу дентину, а саме:

1. Нейтральні глікозаміноглікани - реакції ШйК (реактив Шиффа + йодиста кислота).

2. Відростки одонтобластів - реакції ШЙК + тіоніновий синій.

3. Кислі глікозаміноглікани - альціановим синім у комбінації з ШИК-реакцією.

4. Фосфоліпіди - забарвлення нільським голубим.

Запропонований комплекс гістохімічних барвників дозволяє виявити не тільки преколагенові та колагенові структури, а й відростки одонтобластів та фосфоліпідні мембрани, що їх оточують. Такий підхід дозволяє виявити також відмінності організації дентину між жінками та чоловіками. Також проводились морфометричні дослідження дентинних канальців у навколопульпарному шарі дентину.

Результати досліджень та їх обговорення. 3 результатів проведених досліджень встановлено, що у навколопульпарній зоні дентину коронок великих кутніх зубів локалізуються монопедичні відростки одонтобластів. Тобто від цитоплазми кожного одонтобласта, який розміщується біля мікросудин пульпи, відходить один цитоплазматичний відросток.

Результати проведених мікроскопічних досліджень декальцинованих великих кутніх зубів виявили, що структура одонтобластів та їх монопедичних відростків дещо відрізняється у чоловіків порівняно 3 жінками. У рогах пульпової камери в чоловіків одонтобласти мають багаторядну структуру (рис.1).

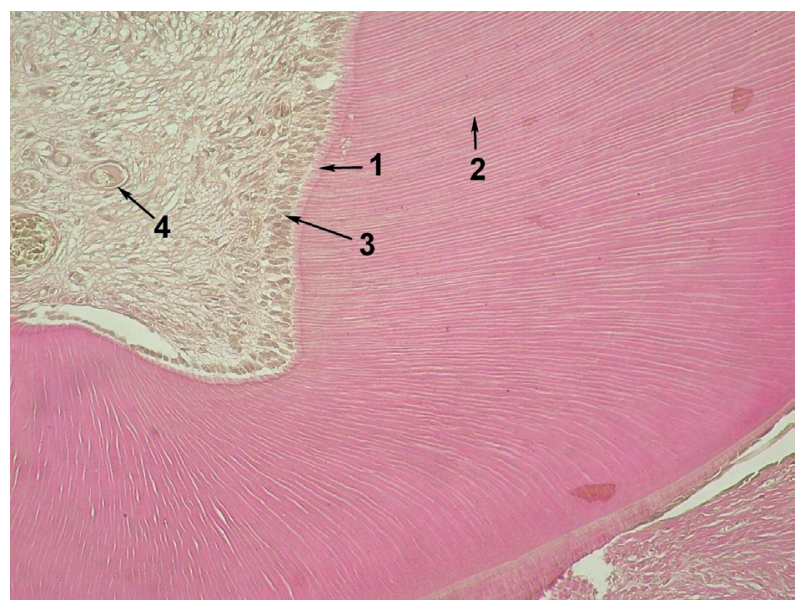

Puc. 1. Навколопульпарний дентин великого кутнього зуба чоловіка:

1 - предентин; 2 - дентинні трубочки;

3 - багаторядне розташування ядер одонтобластів; 4 - мікросудини пульпи.

Декальцинований зуб. Забарвлення пікрофуксином за ван-Гізон. $× 200$.

Це, на нашу думку, зумовлено тим, що функціонально активні одонтобласти підходять ближче до предентину. Завдяки цьому щільність монопедичних дентинних відростків складає 90 канальців на 96 ядер, тобто майже 1:1.

У жінок при підрахунку відношення дентинних відростків до багаторядного розташування ядер складає 70:71, тобто 1:1 (рис. 2).

На нашу думку, різна кількість відростків одонтобластів у чоловіків і жінок зумовлена більшою васкуляризацією рогів пульпи в чоловіків, ніж у жінок.

Як показують гістохімічні дослідження при забарвленні ШЙК-тіоніновим синім, монопедичні відростки одонтобластів за- 


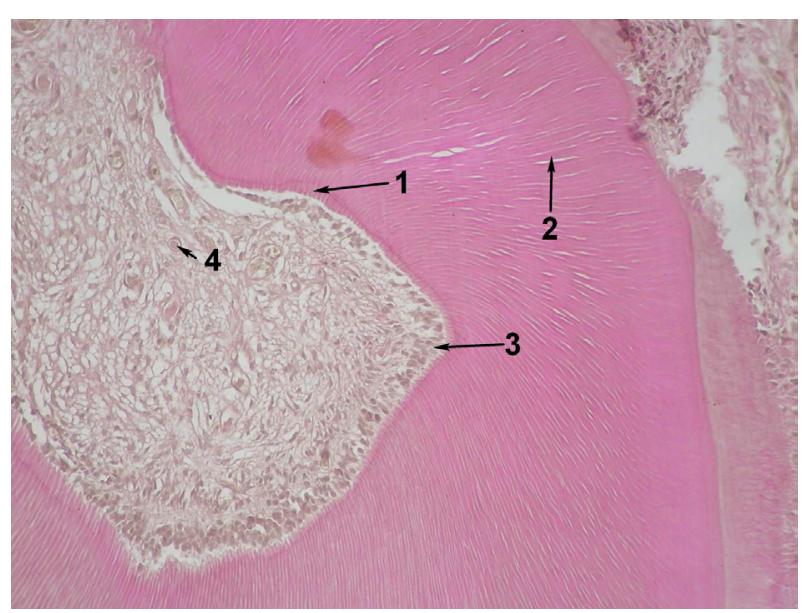

Puc. 2. Навколопульпарний дентин великого кутнього зуба жінки:

1 - предентин; 2 - дентинні трубочки; 3 - багаторядне розташування ядер одонтобластів; 4 - мікросудини пульпи. Декальцинований зуб. Забарвлення пікрофуксином за ван-Гізон. $\times 200$.

барвлюються в темно-синій колір. На поздовжніх зрізах монопедичні відростки одонтобластів, що виходять з пульпової камери, мають паралельний хід і при переході на регулярний шар дентину розділяються. Завдяки цьому на 32 монопедичних відростках одонтобластів міститься 50-60 дихотомічних дентинних трубочок, тобто монопедичні відростки подвоюються в зоні регулярного дентину трансформуючись у дихотомічні (рис. 3).

Результати морфометричних досліджень навколопульпарного дентину

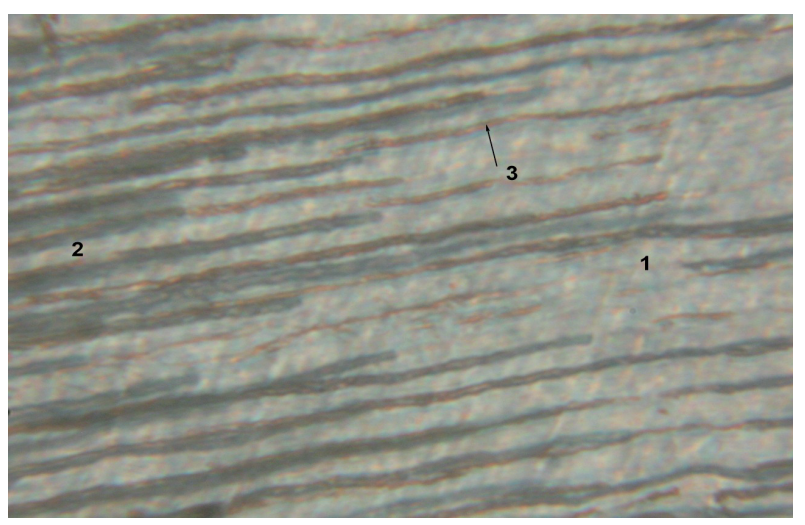

Puc. 3. Монопедичні відростки одонтобластів навколопульпарного дентину великих кутніх зубів:

1 - зона монопедичних відростків; 2 - зона дихотомічних відростків; 3 - дентинні канальця.

Поздовжній шліф. Забарвлення: тіоніном. Епімікроскопія. $\times 700$. підтверджуються результатами епімікроскопічних гістохімічних досліджень поперечних шліфів, забарвлених ШйКводним голубим. Так, проведений підрахунок свідчить, що щільність відростків одонтобластів, забарвлених у темнофіолетовий колір, складає 120 в полі зору. Звертає на себе увагу, що у предентині, забарвленому в червоний колір, виявляються тонкі преколагенові структури, які радіально відходять від відростків одонтобластів.

При проведенні епімікроскопічного дослідження пеперечних шліфів гістохімічно забарвлених нільським голубим виявлено деяку різницю як в інтенсивності забарвлення, так і в щільності окремих дентинних трубочок.

Крім того, проводили підрахунок діаметра монопедичних відростків окремо у чоловіків і жінок на 10 ділянок поля зору, результати якого представлено в таблиці 1.

Проведений підрахунок середнього діаметра дентинних відростків навколопульпарного дентину складає $\mathrm{M} \pm \mathrm{m}$ $(0,996 \pm 0,201)$.

Проведене морфометричне дослідження поперечного перерізу дентинних монопедичних відростків у чоловічих та жіночих зубах свідчить, що їх діаметр не залежить від статі.

Також визначено кількість ядер та дентинних трубочок у ділянці рогів пульпи, які пронизують предентин та їх відгалуження окремо у чоловіків та жінок. Результати морфометричних досліджень у 5 ділянках поля зору представлено в таблиці 2.

Встановлено, що у чоловіків середня кількість ядер одонтобластів складає 92,8, а кількість дентинних трубочок у предентині 88,0. Проте співвідношення цих показників незначною мірою відрізняється в усіх площах полів зору і складає $1,08 \pm 0,02$.

Ужінок спостерігають меншу варіабельність як кількості ядер одонтобластів 70,2, так і кількості дентинних трубочок 67,0 на площу поля зору, але, як і в чоловіків, співвідношення цих показників 1,06 $\pm 0,01$. Ці дані свідчать, що статистично достовірної різниці немає. 
Tаблищя 1. Морфометричні показники діаметра дентинних відростків навколопульпарного дентину

\begin{tabular}{|c|c|c|c|c|c|c|c|c|c|c|}
\hline $\begin{array}{l}\text { Номер } \\
\text { фото }\end{array}$ & 1 & 2 & 3 & 4 & 5 & 6 & 7 & 8 & 9 & 10 \\
\hline Стать & \multicolumn{5}{|c|}{ Чоловіки } & \multicolumn{5}{|c|}{ Жінки } \\
\hline Діаметр & $1,20 \pm 0,08$ & $1,50 \pm 0,09$ & $1,00 \pm 0,07$ & $1,10 \pm 0,07$ & $1,20 \pm 0,08$ & $0,80 \pm 0,05$ & $1,20 \pm 0,08$ & $0,27 \pm 0,02$ & $1,00 \pm 0,07$ & $0,94 \pm 0,06$ \\
\hline (нм) & $0,93 \pm 0,06$ & $1,00 \pm 0,07$ & $0,90 \pm 0,06$ & $0,86 \pm 0,05$ & $1,30 \pm 0,08$ & $0,90 \pm 0,06$ & $0,90 \pm 0,06$ & $1,10 \pm 0,07$ & $1,00 \pm 0,07$ & $1,30 \pm 0,08$ \\
\hline $\begin{array}{l}\text { дентинних } \\
\text { відростків }\end{array}$ & $0,80 \pm 0,05$ & $1,00 \pm 0,07$ & $0,80 \pm 0,05$ & $0,80 \pm 0,05$ & $1,00 \pm 0,07$ & $0,90 \pm 0,06$ & $0,90 \pm 0,06$ & $0,97 \pm 0,06$ & $0,50 \pm 0,03$ & $0,80 \pm 0,05$ \\
\hline
\end{tabular}

Таблищя 2. Співвідношення кількості ядер та дентинних трубочок у предентині в чоловіків та жінок

\begin{tabular}{|c|c|c|c|c|c|c|}
\hline \multirow{2}{*}{$\begin{array}{c}\text { № } \\
\text { 3/п }\end{array}$} & \multicolumn{3}{|c|}{ Чоловіки } & \multicolumn{3}{c|}{ Жінки } \\
\cline { 2 - 7 } & кількість ядер & $\begin{array}{c}\text { кількість дентин- } \\
\text { них трубочок }\end{array}$ & відношення & $\begin{array}{c}\text { кількість } \\
\text { ядер }\end{array}$ & $\begin{array}{c}\text { кількість дентинних } \\
\text { трубочок }\end{array}$ & відношення \\
\hline 1 & 96 & 86 & $1,17 \pm 0,02$ & 71 & 70 & $1,01 \pm 0,01$ \\
\hline 2 & 91 & 89 & $1,02 \pm 0,02$ & 64 & 59 & $1,08 \pm 0,01$ \\
\hline 3 & 94 & 90 & $1,04 \pm 0,02$ & 74 & 70 & $1,06 \pm 0,01$ \\
\hline 4 & 89 & 84 & $1,06 \pm 0,02$ & 78 & 76 & $1,03 \pm 0,01$ \\
\hline 5 & 94 & 91 & $1,03 \pm 0,02$ & 64 & 60 & $1,07 \pm 0,01$ \\
\hline$\Sigma$ & 92,8 & 88,0 & $1,08 \pm 0,02$ & 70,2 & 67,0 & $1,06 \pm 0,01$ \\
\hline
\end{tabular}

Проведене визначення щільності дентинних відростків у навколопульпарному дентині показало, що у чоловіків на поперечному шліфі, забарвленому шйКтіоніном, складає 57000 на стандартну одиницю площі, тобто на 1 мм$^{2}$. Разом 3 тим, у жінок цей показник менший і складає 50000 на таку саму одиницю площі, тобто на 1 мм² $^{2}$.

Одержані морфометричні показники навколопульпарного дентину, на перший погляд, видаються пародоксальними. Так, незважаючи на приблизно однакове співвідношення кількості ядер одонтобластів до їх відростків у рогах пульпи чоловіків та жінок, щільність їх у перших більша, ніж у других.

Висновки. За результатами проведених гістохімічних та морфологічних досліджень навколопульпарного дентину в чоловіків і жінок можна зробити висновок, що в рогах пульпової камери розміщуються багаторядні структури ядер одон-

\section{Список літератури}

1. Гасюк А. П. Атлас одонтогліфіки людини / А. П. Гасюк, П. М. Скрипніков. - Видавництво «Полтава», 2001. - 87 с.

2. Гасюк А. П. Структурно-биохимическая организация дентина / А. П. Гасюк, Т. В. Новосельце- тобластів, клітини яких майже повністю співпадають з кількістю дентинних трубочок у цій ділянці. Проте виходячи з зони предентину в регулярній ділянці кількість детинних трубочок подвоюється. У чоловіків, на відміну від жінок, контури перитубулярного дентину більш чіткі завдяки їх більшій товщині. Тому саме завдяки цьому щільність дентинних трубочок у навколопульпарному дентині в чоловіків більше, ніж у жінок.

На нашу думку, з біохімічної точки зору, важливим $є$ вперше виділена наявність нільськопозитивних мембран Неймана, які оточують монопедичні відростки, і завдяки своїм властивостям можуть пасивно переносити з відростків одонтобластів на перитубулярний дентин складові простетичні елементи колагену. Завдяки цьому, в навколопульпарному дентині формуються тонкі радіальні елементи преколагену, які беруть участь в утворенні колагену I, II і VII типів, що складає органічний матрикс дентину.

ва, Н. В. Ройко, Е. А. Писаренко // Вісник проблем біології та медицини. - 2014. - Вип. 4, т. 3(115). с. 11-15.

3. Гасюк А. П. Особые эпимикроскопические структкры емали и дентина зуба / А. П. Гасюк, 
Т. В. Новосельцева, А. П. Костиренко // Вісник проблем біології і медицини. - 2013. - Вип. 4, т. 1(104) С. 251-252.

4. Морфо- і гістогенез основних стоматологічних хвороб / П. А. Гасюк, А. П. Гасюк, С. І. Данильченко, Н. В. Гасюк. - Тернопіль : ФОП Пархін Р. А., 2016. - 104 c.

5. Гасюк П. А. Епімікроскопічні особливості будови емалево-дентинної межі та інтерглобулярного дентину великих та малих кутніх зубів у віковому аспекті / П. А. Гасюк, А. Б. Воробець, В. Є. Пудяк // Інновації в стоматології. - 2014. - № 2(4). - С. 96-97. 6. Гасюк П. А. Епімікроскопічні особливості будови інтерглобулярного дентину зубів у віковому аспекті / П. А. Гасюк // Вісник наукових досліджень. - 2013. - № 3. - С. 99-100.

7. Ковальов $€$. В. Вивчення мікротвердості емалі та дентину різців у нормі і при патологічних станах / Є. В. Ковальов, М. А. Шундрик, Л. С. Амосова // Український стоматологічний альманах. - 2012. - № 6. - C. 25-27.

8. Костиленко Ю. П. Структура зубной эмали и ее связь с дентином / Ю. П. Костиленко, И. В. Бойко // Стоматология. - 2005. - № 5. - С. 10-13.

9. Луцкая И. К. Возрастная физиология зуба. Сообщение 1. Возрастная морфология эмали и дентина постоянных зубов человека / И. К. Луцкая // Современная стоматология - 1997. - № 3. - С. 7-12.
10. Ремизов С. М. Микромеханические характеристики реставрационных стоматологических материалов, эмали и дентина зубов человека / С. М. Ремизов, В. М. Скворцов // Стоматология. 2006. - № 4. - С. 28-33.

11. Черняк В. В. Розвиток карієсу молярів в аспекті антропологічних показників різних класів зубів / В. В. Черняк // Світ медицини та біології. - 2008. - № 2. - С. 98-101.

12. Ясвоин Г. В. О дифференцировке тканей зубной пульпы и образований дентина / Г. В. Ясвоин // Современные проблемы стоматологии. - М. ; Л., 1999. - C. 66-95.

13. Bonecker M. Clinical, histological and microbiological study of hand-excavated carious dentine in extracted permanent teeth / M. Bonecker, E. Grossman, R. Parak // SADJ. - 2003. - Vol. 58, No. 7. P. 273-278.

14. Chen S. Binding of Two Nuclear Factor to a Novel Silencer Element in Human Dentin Matrix Protein (DMP-I) Promotor Regulates the Cell Type-specific DMP-I Gene Expression / S. Chen, N. InozentsevaClynton, J. Dong // Cell Biochim. - 2007. - Vol. 92(2). P. 332-349.

15. Harazanan K. Different Expression Patterns of Dentin Matrix Protein During Mineralized Tissue Formation / K. Harazan, A. George // Bone. - 2004. Vol. 34(6). - P. 21-32. 